the degree of economic, social and ethnic tension in Russia and, at its borders, by Western immigration quotas and regulations. In general terms the demand for nonqualified workers is very low in the West. This situation is very different from that which existed in the 1960s when the mass emigration of nonqualified workers was welcomed. Then the stream of immigrants to Western Europe and North America had a positive economic impact on the West. Russian reforms allowing freedom of emigration were 30 years too late to take advantage of those conditions.

- The high proportion of professionals and highly educated people among emigrants from Russia today testifies to the negative impact of emigration on the intellectual potential of Russia. Comparing the qualitative features of emigration and immigration, we see a looming danger of migration imbalance: the departure of highly qualified workers and the arrival of less qualified immigrants from the "near abroad."

There is little possibility that the emigration/immigration situation can be transformed without radical socioeconomic and political improvements in Russia. Some of the negative impact can be diminished by firmly establishing the state borders of Russia and by concluding bilateral and multinational international treaties on the legal regulation of migration. But even these changes will not affect the fundamental cause of contemporary migration in Russia: the aggravation of ethnic relations throughout the region due to the post-socialist transformation.

The countries of Western Europe are pluralist democracies in a postnationalistic phase of their existence. ${ }^{34}$ They have developed among themselves various forms of economic, social, cultural, and political cooperation. In contrast, the countries of Eastern Europe and Central Asia are going through a very painful process of forming their own democratic principles. This is accompanied by the growth of nationalism and national intolerance, when the rights of national groups have higher priority than general human rights, when xenophobia is spreading, when administrative forces are crumbling, when a war of laws is being prosecuted, and when territorial claims and national conflicts are leading to confrontations involving the use of force.

It is difficult to foresee how long this transitional period will continue. It is, however, very likely that the passage of Eastern Europe and Central Asia to higher levels of national tolerance will have to be analyzed by a future generation of social scientists.

\section{Afterword to the English Edition}

Analysis of the most recent data concerning the migration situation in Russia at the beginning of 1994 confirms the further development of all the tendencies mentioned above.

For example, the flow of migrants continues to increase and the rate of natural increase continues to decline. Thus the highest rate of in-migration since World War II $(430,000$ in 1993) could not compensate for the diminution of the Russian population due to natural causes by 737,000 in the same year.

The flow of (mainly Russian) migrants from Central Asia, Transcaucasus and Kazakhstan to Russia is also intensifying. In 1993, these regions accounted for two-thirds of the total number of immigrants to Russia. Russians make up 62 percent of all refugees.

Russia continues to maintain a negative net migration balance with Belarus and Ukraine, and with Western countries and Israel. In 1993, emigration of Russians to foreign countries outside the former USSR exceeded the level of the previous few years. Some 115,900 people left for abroad in 1993, 11 percent more than in the previous year.

In a like fashion, other tendencies analyzed in the text are corroborated by up-to-date data. The past year has witnessed a worsening of the criminal situation in regions of mass concentration of migrants, a growing threat of migration imbalance, an intensification of economic and political problems connected with the absorption of new settlers, etc. The gravity of the economic, social, demographic and political consequences of migration-not only for Russia, but for the world as a whole-will thus require much scientific study in the years ahead.I

\section{Notes}

1. The "near abroad" refers to the former Soviet republics outside Russia.

2. Information Reference of the State Statistics Committee of the Russian Federation. 1993. No. 17-1-16/11, January 14.

3. Institute for Sociopolitical Research. 1993. The Social and Sociopolitical Situation in Russia: Conditions and Forecast, 1992, $\mathrm{p}$ 62. Moscow: Russian Academy of Science.

4. Information Reference... op. cit.

5. Information Reference... op. cit.

6. State Statistics Committee of the Russian Federation and the Ministry of Internal Affairs. 1991. Materials of the Selective Research on Reasons for Migration. Moscow. (The survey was carried out at the end of 1991 over a period of 35 days. Respondents were 16 years of age and over. They were interviewed in 23 Russian locations where they had settled.)

7. The titular national group is the native ethnic group from which a territory derives its name, e.g., Ukrainians in Ukraine.

8. Republic Long-term "Migration" Programme. 1992. May 18:6.

9. The Criminal Situation and Social Tension in the Russian Federation in 1992. 1993. Moscow: Minister of Internal Affairs of the Russian Federation: 78.

10. In this section we cite results of a sociological survey reported in The Social and Sociopolitical Situation in Russia: Conditions and Forecast, 1992 (Moscow: Institute for Sociopolitical Research, Russian Academy of Science, 1992) pp. 48-54.

11. TASS Information. Kompas. 1992. No. 242, December 15. 